(c) American Dairy Science Association, 2003.

\title{
The Impact of Fermentation and In Vitro Digestion on the Formation of Angiotensin-I-Converting Enzyme Inhibitory Activity from Pea and Whey Protein
}

\author{
V. Vermeirssen, ${ }^{\star} \dagger$ J. Van Camp, $†$ K. Decroos, ${ }^{*}$ L. Van Wijmelbeke, $\dagger$ and W. Verstraete ${ }^{\star}$ \\ *Department of Biochemical and Microbial Technology \\ †Department of Food Technology and Nutrition, \\ Faculty of Agricultural and Applied Biological Sciences, Ghent University, \\ 9000 Ghent, Belgium
}

\section{ABSTRACT}

Pea and whey protein were fermented by Lactobacillus helveticus and Saccharomyces cerevisiae in monoculture and in combination at 28 and $37^{\circ} \mathrm{C}$ in order to release angiotensin-I-converting enzyme (ACE) inhibitory peptides. The fermentation products were subjected to in vitro gastrointestinal digestion, and the digests of nonfermented samples served as controls. After fermentation, the ACE inhibitory activity (\%) increased by 18 to $30 \%$ for all treatments, except for the fermentations of whey protein with Saccharomyces cerevisiae at $28^{\circ} \mathrm{C}$, where no significant change was observed. After digestion, however, both fermented and nonfermented samples reached maximum ACE inhibitory activity. The whey digests tended to have lower (50\%) inhibitory concentrations ( $\mathrm{IC}_{50} ; 0.14$ to $0.07 \mathrm{mg} /$ $\mathrm{ml}$ ), hence, higher ACE inhibitory activity, than the pea digests $(0.23$ to $0.11 \mathrm{mg} / \mathrm{ml})$. The nonfermented whey protein digest showed the highest ACE inhibitory activity of all. For pea protein, the nonfermented sample had the lowest $\mathrm{IC}_{50}$ value. These results suggest that in vitro gastrointestinal digestion was the predominant factor controlling the formation of ACE inhibitory activity, hence, indicating its importance in the bioavailability of ACE inhibitory peptides.

(Key words: ACE inhibitory peptide, fermentation, gastrointestinal digestion)

Abbreviation key: ACE = angiotensin-I-converting enzyme, GRAS = generally recognized as safe, $\mathbf{I C}_{\mathbf{5 0}}$ $=50 \%$ inhibitory concentration, $\mathbf{M W C O}=$ molecular weight cut off, $\mathbf{S H R}=$ spontaneously hypertensive rats.

\section{INTRODUCTION}

Hypertension is a major risk factor for the development of cardiovascular diseases, which is one of the

Received June 14, 2002.

Accepted September 4, 2002.

Corresponding author: W. Verstraete; e-mail: willy.verstraete@ rug.ac.be. main causes of mortality in Western countries (Duprez et al., 2002). Diet and lifestyle modification represent effective tools in the prevention of hypertension. In the treatment of the disease, these diet and lifestyle changes can decrease requirements of antihypertensive medication, as well as have beneficial effects related to hypertension not remedied by most drugs (Hermansen, 2000). In this respect, functional foods with blood pressure-lowering properties have recently received considerable attention.

Angiotensin-I-converting enzyme (ACE; EC 3.4.15.1) is a dipeptidyl carboxypeptidase that elevates blood pressure by producing the vasoconstrictor angiotensin II and degrading the vasodilator bradykinin (Campbell, 1987). ACE inhibitory peptides have already been isolated from many food proteins (Dziuba et al., 1999; Fitzgerald and Meisel, 2000). Fermentation and/or digestion are popular food processing steps to release these bioactive or functional peptides from food proteins (Abubakar et al., 1998; Gobbetti et al., 2000). After oral administration, the ACE inhibitory peptides may exert an antihypertensive effect, provided they pass the gastrointestinal digestive and absorptive system and reach the cardiovascular system in an active form.

Recently, certain functional foods containing ACE inhibitory peptides have been shown to act as an additional or alternative treatment in hypertension. Daily administration of Calpis sour milk to hypertensive human subjects significantly reduces their blood pressure. The antihypertensive effect of this milk fermented with a starter containing Lactobacillus helveticus and Saccharomyces cerevisiae, is due to the presence of the ACE inhibitory peptides Val-Pro-Pro and Ile-Pro-Pro, contained in the primary structure of $\beta$-casein, and $\beta$ casein and $\kappa$-casein, respectively (Takano, 1998). Moreover, long-term intake of Val-Pro-Pro and Ile-Pro-Pro, or a sour milk containing these tripeptides attenuates the development of hypertension in spontaneously hypertensive rats (SHR), suggesting a preventive role of ACE inhibitory peptides in hypertension as well (Sipola et al., 2001). 
Pea protein is a valuable protein for human nutrition with the advantage of a good balanced profile of amino acids, a high content in the essential amino acid lysine (82 g/kg protein) and good solubility. In addition, it is an environmentally friendly, low-input crop and may represent an alternative to soy. ACE inhibitory peptides derived from pea protein have not yet been reported in literature. In a previous study, high ACE inhibitory activity in a tryptic digest of pea protein isolate was found, suggesting that the pea may be an alternative source of ACE inhibitory peptides (Vermeirssen et al., $2002 b)$. Fermentation was investigated as a means to produce ACE inhibitory peptides, and the ACE inhibitory activity derived from pea protein was compared to the one of whey protein, a known source of ACE inhibitory peptides (Pihlanto-Leppälä, 2001). Eight lactobacilli and Saccharomyces cerevisiae, microorganisms that are already used in food processing were used to inoculate the protein media. The combination of yeast and lactic acid bacteria is often used in fermented milkbased products as several synergistic interactions may occur (Viljoen, 2001). The importance of the gastrointestinal proteases pepsin (A, EC 3.4.23.1), trypsin (EC 3.4.21.4), and $\alpha$-chymotrypsin (EC 3.4.21.1) on the formation and/or degradation of ACE inhibitory peptides was also assessed.

\section{MATERIALS AND METHODS}

\section{Products}

The pea protein isolate Pisane HD and the (rennet) whey protein isolate Lacprodan DI-9213 were obtained from Cosucra SA (Fontenoy, Belgium) and Acatris Belgium NV (Londerzeel, Belgium), respectively. Thiamin, pyridoxine, D-pantothenic acid, inositol, D-biotin, nicotinic acid, riboflavin, pepsin (P 6887), trypsin ( $\mathrm{T}$ 1426), $\alpha$-chymotrypsin (C 4129), trichloroacetic acid solution (490-10), ACE reagent (305-10), ACE control-E (A $7040)$, and $1 \mathrm{~kg} / \mathrm{L}$ trifluoroacetic acid solution (30,2031) were purchased from Sigma-Aldrich (St. Louis, MO, USA). Nonspecified products were analytical grade and came from VWR International (Zaventem, Belgium).

\section{Fermentation}

The following lactobacilli were used in the screening fermentations: Lactobacillus fermentum LMG8900, Lactobacillus gasseri LMG9203, Lactobacillus oris LMG9848, Lactobacillus reuteri LMG9213, Lactobacillus acidophilus LMG7943, Lactobacillus plantarum LMG9211, Lactobacillus plantarum LMG9212, and Lactobacillus helveticus LMG 11474 (LMG Culture Collection, Ghent University, Belgium). The first seven microorganisms originated from humans, while the last was derived from a Swiss cheese starter. In the subsequent fermentations, Saccharomyces cerevisiae (commercial baking yeast) was used as well. Lactobacilli were propagated in MRS broth (de Man, Rogasa, Sharpe; Oxoid, Basingstoke, UK) under micro-aerophilic conditions at $37^{\circ} \mathrm{C}$ for $24 \mathrm{~h}$ and baking yeast in YPD broth (10 g/L Yeast extract; Oxoid), $10 \mathrm{~g} / \mathrm{L}$ Peptone bacteriological (Oxoid; $20 \mathrm{~g} / \mathrm{L}$ D-glucose) under aerobic conditions at $28^{\circ} \mathrm{C}$ for $24 \mathrm{~h}$.

The screening fermentations were carried out with pea protein only, for $48 \mathrm{~h}$ at $37^{\circ} \mathrm{C}$. Fermentations with Lactobacillus helveticus and Saccharomyces cerevisiae occurred in monoculture at their optimal temperature (37 and $28^{\circ} \mathrm{C}$, respectively) and in combination (37 and $28^{\circ} \mathrm{C}$ ) for $48 \mathrm{~h}$ on both pea and whey protein. At the start of the fermentation, the selected microorganisms were added to the fermentation medium under sterile conditions in a concentration of $6.3 \log _{10} \mathrm{cfu} / \mathrm{ml}$ for $L$. helveticus and $5.7 \log _{10} \mathrm{cfu} / \mathrm{ml}$ for S. cerevisiae. Samples at the start of the fermentation were taken for analysis. Then the inoculated fermentation medium was incubated at 28 or $37^{\circ} \mathrm{C}$ for $48 \mathrm{~h}$, after which fermented samples were taken. Finally, the fermented medium was subjected to an in vitro gastrointestinal digestion and a last sampling took place. Fermentation experiments with $L$. helveticus or/and $S$. cerevisiae were repeated at least three times.

The fermentation medium was composed as follows: $40 \mathrm{~g} / \mathrm{L}$ protein, $20 \mathrm{~g} / \mathrm{L}$ D-glucose, $10 \mathrm{ml} / \mathrm{L}$ vitamin solution, $10 \mathrm{ml} / \mathrm{L}$ salt solution, and $0.1 M$ sodium phosphate buffer, $\mathrm{pH} 6$ to 6.5. To avoid the Maillard reaction, the protein solution and the rest solution, consisting of $\mathrm{D}$ glucose and salt solution in sodium phosphate buffer, were autoclaved separately for $15 \mathrm{~min}$ at $121^{\circ} \mathrm{C}, 101.3$ $\mathrm{kPa}$ overpressure. The salt solution contained (per liter) $5 \mathrm{~g}$ of $\mathrm{MgSO}_{4} \cdot 7 \mathrm{H}_{2} \mathrm{O}, 5 \mathrm{~g}$ of $\mathrm{KH}_{2} \mathrm{PO}_{4}, 1 \mathrm{~g}$ of $\mathrm{CaCl}_{2} \cdot 2 \mathrm{H}_{2} \mathrm{O}$, and $0.5 \mathrm{~g}$ of $\mathrm{MnSO}_{4} \cdot \mathrm{H}_{2} \mathrm{O}$. The vitamin solution consisted of (per liter) $40 \mathrm{mg}$ of thiamine, $40 \mathrm{mg}$ of pyridoxine, $40 \mathrm{mg}$ of D-pantothenic acid, $200 \mathrm{mg}$ of inositol, $2 \mathrm{mg}$ of D-biotin, $40 \mathrm{mg}$ of nicotinic acid, and $40 \mathrm{mg}$ of riboflavin. It was added to the autoclaved fermentation medium after sterilization by $0.22 \mu \mathrm{m}$ filtration (Millipore, Bedford, MA). Before inoculation, the $\mathrm{pH}$ of the $100 \mathrm{ml}$ whey protein fermentation medium was adjusted to $\mathrm{pH}$ 6 to 6.5 by the addition of $450 \mu \mathrm{l} 10 \mathrm{M} \mathrm{NaOH}$.

\section{Digestion}

The conditions of the physiological digestion were based on literature (Gauthier et al., 1986; Ganong, 1997; De Boever et al., 2000). To simulate the digestion in the stomach, the $\mathrm{pH}$ of the fermented medium was adjusted to 2 with $10 \mathrm{M}$ and $1 \mathrm{M} \mathrm{HCl}$ under rigorous mixing. Subsequently, pepsin was supplemented in an 
enzyme to substrate ratio of 1 over 250 , and the medium was incubated on a shaker for $2 \mathrm{~h}$ at $37^{\circ} \mathrm{C}$. Next, the small intestinal digestion was simulated by setting the $\mathrm{pH}$ at 6.5 with $10 M$ and $1 M \mathrm{NaOH}$ under rigorous mixing and by addition of trypsin and $\alpha$-chymotrypsin, both in an enzyme to substrate ratio of 1 over 250 , followed by another incubation for $2.5 \mathrm{~h}$ on a shaker at $37^{\circ} \mathrm{C}$. At the end of digestion, the $\mathrm{pH}$ was adjusted to 5 with $10 M$ and $1 M \mathrm{HCl}$. As this is a pH near the isoelectrical point for both proteins (pea: $\mathrm{pH} 4.5$, whey: $\mathrm{pH} 4$ to 5), a standardized and clear separation was obtained by subsequent centrifugation.

\section{Followup of the Fermentation}

At the start and the end of the fermentation, $\mathrm{pH}$ was measured using a $744 \mathrm{pH}$ Meter (Metrohm, Herisau, Switzerland), and plate counts were performed after 72 $\mathrm{h}$ of incubation at $37^{\circ} \mathrm{C}$ on Rogosa agar (Oxoid) and at $28^{\circ} \mathrm{C}$ on YPD agar (YPD broth $+20 \mathrm{~g} / \mathrm{L}$ agar) for lactobacilli and $S$. cerevisiae, respectively.

\section{Degree of Proteolysis}

The degree of proteolysis was determined by the ratio of the nonprotein Kjeldahl nitrogen to the total Kjeldahl nitrogen. Samples for nonprotein nitrogen determination were treated with trichloroacetic acid solution to a final concentration of $60 \mathrm{~g} / \mathrm{L}$, shaken for $5 \mathrm{~min}$, and then centrifuged at $12,000 \times g$ for $10 \mathrm{~min}$ at $4^{\circ} \mathrm{C}$. This supernatant and a sample for total nitrogen determination were stored at $-70^{\circ} \mathrm{C}$ prior to analysis.

\section{ACE Inhibitory Activity}

Samples for ACE inhibition were centrifuged at $10,000 \times g$ for $15 \mathrm{~min}$ at $4^{\circ} \mathrm{C}$, the supernatant was frozen in liquid nitrogen, and stored at $-70^{\circ} \mathrm{C}$. Next, the frozen samples were lyophilized during $3 \mathrm{~d}$ to obtain a dry powder. Lyophilized powder $(10 \mathrm{mg})$ was dissolved in $1 \mathrm{ml}$ of demineralized water and analyzed by the ACE inhibition assay as described by Vermeirssen et al. (2002b), with the modification that pure ACE from porcine kidney (ACE control-E), was used. By this spectrophotometric method, ACE inhibition is measured using the substrate furanacryloyl-Phe-Gly-Gly. The reaction mixture contained $500 \mu \mathrm{l} \mathrm{ACE}$ reagent, $300 \mu \mathrm{l}$ demineralized water (blank) or inhibitor solution, and $300 \mu \mathrm{l}$ ACE control-E. The decrease in absorbance at $340 \mathrm{~nm}$ over 5 min corresponded to an ACE activity (U/L) as determined by the standard curve, and a percentage of ACE (inhibitory) activity, assuming that the ACE (inhibitory) activity of the blank is 100\% (0\%). The detection limit of the ACE inhibitory activity assay is $11 \%$.
When ACE inhibitory activity exceeded $80 \%$, dilution series were made to determine the $50 \%$ inhibitory concentration $\left(\mathbf{I C}_{\mathbf{5 0}}\right)$ value. The latter is defined as the concentration of inhibitory compound in the assay that inhibits 50\% of the ACE activity. Dose-activity curves were generated for doses of inhibitor versus ACE (inhibitory) activity. The $\mathrm{IC}_{50}$ value was obtained by fitting the data to a four parametric logistic model using the Marquardt-Levenberg algorithm (Sigmaplot 4.0, SPSS Inc., Chicago, IL).

$$
y=\min +\frac{\max -\min }{1+10^{\left[\log I C_{50}-x\right] . \text { hill slope }}}
$$

In this equation, y represents the ACE inhibitory activity (\%); x, the logarithm of the concentration of inhibitor $(\mathrm{mg} / \mathrm{ml})$; min, the baseline of $0 \%$ inhibition; max, the plateau of $100 \%$ inhibition; and hill, slope the slope of the curve at the transition center $\mathrm{IC}_{50}$. ACE inhibition analysis was repeated three times per sample. Captopril was used to validate the assay and showed a $50 \%$ inhibitory concentration $\left(\mathrm{IC}_{50}\right)$ of $7.5 \mathrm{nM}$ with a $95 \%$ confidence interval of 6.4 to $8.8 \mathrm{n} M$.

\section{Protease Activity}

The protease activity was determined on the supernatant and the redissolved precipitate of the 24-h propagated culture of $L$. helveticus and $S$. cerevisiae, respectively, after centrifugation at $5000 \times \mathrm{g}$ for $10 \mathrm{~min}(\mathrm{n}=$ 3 ). Activity was assessed by means of a commercially available Universal Protease Substrate spectrophotometric assay (Roche Diagnostics, Basel, Switzerland).

\section{HPLC Analysis}

Samples for the HPLC analysis were treated in the same manner as for the ACE inhibition assay. Twentymilligram lyophilized powder was dissolved in 2-ml milli-Q water (Millipore) and ultrafiltrated-centrifuged in Centricon YM-3000 tubes (molecular weight cut-off (MWCO): $3000 \mathrm{Da}$; Millipore) for $2 \mathrm{~h}$ at $7500 \times \mathrm{g}$. The permeate was analyzed by reversed-phase HPLC on a Prosphere $300 \AA \mathrm{C}_{18}$ column $(250 \times 4.6 \mathrm{~mm}, 5 \mu \mathrm{m}$; Alltech Associates, Deerfield, IL) and a Dionex (Sunnyvale, CA) HPLC with an autosampler ASI-100, pump series P580, STH585 column oven, UV-VIS detector UVD340S operating at $210 \mathrm{~nm}$, and Chromeleon 6.0 software. Elution was at $25^{\circ} \mathrm{C}$ with a flow rate of $1 \mathrm{ml} /$ min, a linear gradient from $90 \%$ solvent $\mathrm{A}\left(\mathrm{H}_{2} \mathrm{O}+1 \mathrm{~g} /\right.$ L TFA) to $50 \%$ solvent B (acetonitrile $+0.85 \mathrm{~g} / \mathrm{L} \mathrm{TFA}$ ) in $30 \mathrm{~min}$, again to $90 \%$ solvent $\mathrm{A}$ for the next $20 \mathrm{~min}$, and remaining at $90 \%$ solvent $\mathrm{A}$ for the last $10 \mathrm{~min}$. 


\section{Sonication}

Sonication (Sonicator 250, Branson, G. Heinemann, Schwäbisch Gmünd, Germany) was performed in the ice-cooled, 24-h propagated culture of L. helveticus, $S$. cerevisiae, or a combination of both $[1 / 1$ ( $\mathrm{vol} / \mathrm{vol})$ propagated culture of both microorganisms] to release the intracellular proteases from the lysed cells in the medium. Operational parameters resulting in the highest protease activity as obtained with the commercial protease assay were found to be: time $=12 \mathrm{~min}$, output control $=3$ and duty cycle $=70 \%$. A $40-\mathrm{g} / \mathrm{L}$ whey or pea protein solution in demineralized water was incubated with 10-ml/L lysed cell suspensions of $S$. cerevisiae at $28^{\circ} \mathrm{C}$ or L. helveticus or both at $37^{\circ} \mathrm{C}$ for $24 \mathrm{~h}$.

\section{Statistical Analysis}

All values, except $\mathrm{IC}_{50}$, are reported as mean \pm standard error of the mean $\left(\mathrm{n}_{\min }=3\right)$. Some missing values ( $2 \%$ of the dataset) were replaced by the average. A paired Student's $t$-test studied the significance of changes in $\mathrm{pH}$, lactobacilli, and yeast counts during fermentation. To exclude the initial effect of the protein itself, the statistical analysis was performed on the changes in degree of proteolysis and ACE inhibitory activity during fermentation, and fermentation and digestion. By means of the general linear model procedure (Minitab 11.21, State College, PA) significant differences in type of protein and type of fermentation were assigned. When there was a significant type of protein $\times$ type of fermentation interaction, for both proteins a Oneway ANOVA analysis was carried out in type of fermentation. All data used in the variance analysis met the homogeneity of variance requirement assessed by Bartlett's test for normal and Levene's test for notnormal distributions. Normality was tested by means of the Anderson-Darling criterion. Indication of subgroups was done by Tukey post hoc test $(P<0.05)$. For the comparison of the heteroscedastic $\log \mathrm{IC}_{50}$ values, obtained from the 4 parametric logistic model, the Games-Howell method was used $(P<0.05$; Sokal and Rohlf, 1995). IC $_{50}$ values are reported as mean and $95 \%$ confidence interval.

\section{RESULTS}

\section{Screening of Lactobacilli}

Eight different generally recognized as safe (GRAS) lactobacilli were screened for the production of $\mathrm{ACE}$ inhibitory activity during fermentation and subsequent in vitro gastrointestinal digestion of pea protein (Table
1). Fermentation with $L$. helveticus yielded the highest ACE inhibitory activity and was, therefore, selected for subsequent experimentation. After in vitro digestion, all ferments reached high to maximal ACE inhibitory activity.

\section{Fermentation by Lactobacillus helveticus and/or Saccharomyces cerevisiae}

Autoclaved pea and whey protein medium were fermented with $L$. helveticus at $37^{\circ} \mathrm{C}, S$. cerevisiae at $28^{\circ} \mathrm{C}$, or a combination of both microorganisms at 28 or $37^{\circ} \mathrm{C}$ in order to produce ACE inhibitory active ferments. Fermentation was always followed by an in vitro gastrointestinal digestion with pepsin at $\mathrm{pH} 2$ and a combination of trypsin and chymotrypsin at $\mathrm{pH}$ 6.5. Nonfermented autoclaved pea and whey protein medium, subjected to in vitro gastrointestinal digestion, served as control experiments.

The presence of $L$. helveticus at its optimal temperature of $37^{\circ} \mathrm{C}$ initiated a large $\mathrm{pH}$ decrease during fermentation (Table 2). The $\mathrm{pH}$ after fermentation was lower for pea than for whey $(P<0.001)$. L. helveticus counts increased during fermentation in monoculture on both protein media. However, this lactic acid bacterium hardly grew in the presence of the yeast, both at 37 and $28^{\circ} \mathrm{C}$, for pea and whey protein (Table 2). $S$. cerevisiae counts increased during fermentation at $28^{\circ} \mathrm{C}$, whether or not in the presence of $L$. helveticus. A higher, nonoptimal temperature, e.g., $37^{\circ} \mathrm{C}$, was disadvantageous for the yeast. Hence, the growth of both microorganisms was affected by the type of fermentation $(P<0.001)$ but in a different manner. The counts of both microorganisms did not differ significantly between the two proteins.

\section{Degree of Proteolysis and ACE Inhibitory Activity in Ferments and Digests}

At the start of the fermentation process, the degree of proteolysis for pea, $6.7 \pm 0.4 \%$, was lower than for whey, $17.9 \pm 0.5 \%(P<0.001)$. The ACE inhibitory activity of the fermentation medium of pea amounted to 16 $\pm 2 \%$, while for whey this was $63 \pm 2 \%(P<0.001)$. Figure 1 shows the degree of proteolysis and Figure 2 the ACE inhibitory activity, after fermentation and after fermentation and digestion for both proteins. The statistical analysis, however, was performed on the changes of these parameters during fermentation, and fermentation and digestion, in order to exclude the initial degree of proteolysis and ACE inhibitory activity of the protein itself.

The change in degree of proteolysis during fermentation was significantly different between the two pro- 
Table 1. Angiotensin-I-converting enzyme (ACE) inhibitory activity (\%) after fermentation of pea protein medium by different lactobacilli at $37^{\circ} \mathrm{C}$ and subsequent in vitro digestion. The data represent the result of a single experiment.

\begin{tabular}{lcc}
\hline Strain & After fermentation ${ }^{1,2}$ & $\begin{array}{c}\text { After in } \\
\text { vitro digestion }\end{array}$ \\
\hline Lactobacillus fermentum LMG8900 & 12 & 90 \\
Lactobacillus gasseri LMG9203 & 12 & 96 \\
Lactobacillus oris LMG9848 & 16 & 100 \\
Lactobacillus reuteri LMG9213 & 9 & 96 \\
Lactobacillus acidophilus LMG7943 & 13 & 93 \\
Lactobacillus plantarum LMG9211 & 7 & 83 \\
Lactobacillus plantarum LMG9212 & 11 & 99 \\
Lactobacillus helveticus LMG11474 & 37 & 96 \\
\hline
\end{tabular}

\footnotetext{
${ }^{1}$ The concentration of ferment or digest in the assay was $2.73 \mathrm{mg} / \mathrm{ml}$.

${ }^{2}$ The initial ACE inhibitory activity of the pea fermentation medium was $16 \pm 2 \%$.

${ }^{3}$ The ACE inhibitory activity of nonfermented digested pea fermentation medium amounted to $99.3 \pm$ $0.7 \%$.
}

teins $(P=0.033)$ and between the different types of fermentation $(P<0.001)$. The degree of proteolysis increased during fermentation maximally by $15 \%$, in the monoculture fermentation with $L$. helveticus (Figure 1). The fermentation with both $L$. helveticus and $S$. cerevisiae at $37^{\circ} \mathrm{C}$ also increased the degree of proteolysis, more in the pea than in the whey protein medium. In the presence of $S$. cerevisiae at $28^{\circ} \mathrm{C}$, no significant change could be observed, except for the monoculture fermentation with $S$. cerevisiae on whey protein (WY28), where the degree of proteolysis decreased slightly after fermentation $(P<0.05)$. After in vitro digestion, the degree of proteolysis increased sharply in all samples, and the degree of proteolysis in the nonfermented media did not differ from the fermented ones $(P=0.625)$. The less-pronounced increase in degree of proteolysis for the whey protein during digestion compared with the pea protein $(P<0.001)$, can partially be explained by the higher initial degree of proteolysis for the whey protein fermentation medium.

For the pea protein, the type of fermentation did not influence the increase in ACE inhibitory activity after fermentation ( $P=0.539$; Figure 2$)$. For the whey protein, on the other hand, the presence of $L$. helveticus and a temperature of $37^{\circ} \mathrm{C}$ resulted in increased ACE inhibitory activity after fermentation, whereas the presence of $S$. cerevisiae and a temperature of $28^{\circ} \mathrm{C}$ did not $(P<0.001)$. In vitro digestion incrased the ACE inhibitory activity significantly, and both nonfermented and fermented samples reached the maximum level of $100 \%(P=0.959)$. Somewhat due to the high initial ACE inhibitory activity of the whey protein, the increase during digestion was smaller than with the pea protein $(P<0.001)$.

Table 2. $\mathrm{pH}$ and plate counts $\left(\log _{10} \mathrm{cfu} / \mathrm{ml}\right)$ of Lactobacillus helveticus and Saccharomyces cerevisiae after $48 \mathrm{~h}$ fermentation for the different types of fermentations (LH37: L. helveticus at $37^{\circ} \mathrm{C}, \mathrm{Y} 28$ : S. cerevisiae at $28^{\circ} \mathrm{C}$, LHY37: L. helveticus and $S$. cerevisiae at $37^{\circ} \mathrm{C}$, LHY28: L. helveticus and S. cerevisiae at $28^{\circ} \mathrm{C}$ ), for both pea and whey protein $\left(\mathrm{n}_{\min }=3\right)$.

\begin{tabular}{|c|c|c|c|c|}
\hline & & $\mathrm{pH}^{1}$ & L. helveticus ${ }^{2}$ & S. cerevisiae $^{3}$ \\
\hline \multirow[t]{4}{*}{ Pea } & LH37 & $3.5 \pm 0.1^{* * * a}$ & $7.8 \pm 0.4^{* * a}$ & I \\
\hline & Y28 & $5.5 \pm 0.2^{\mathrm{b}}$ & I & $7.1 \pm 0.2^{* * \mathrm{a}}$ \\
\hline & LHY37 & $3.6 \pm 0.1^{* * a}$ & $6.5 \pm 0.3^{\mathrm{b}}$ & $5.6 \pm 0.5^{\mathrm{b}}$ \\
\hline & LHY28 & $5.4 \pm 0.3^{\mathrm{b}}$ & $6.6 \pm 0.4^{\mathrm{b}}$ & $7.7 \pm 0.2^{* a}$ \\
\hline \multirow[t]{4}{*}{ Whey } & LH37 & $3.9 \pm 0.1^{* * * a}$ & $7.4 \pm 0.3^{* * a}$ & I \\
\hline & Y28 & $6.1 \pm 0.0 * * b$ & / & $7.6 \pm 0.1^{* * a}$ \\
\hline & LHY37 & $4.3 \pm 0.2^{* * * a}$ & $6.3 \pm 0.3^{\mathrm{b}}$ & $5.1 \pm 0.2^{* * \mathrm{~b}}$ \\
\hline & LHY28 & $5.9 \pm 0.1^{* b}$ & $6.3 \pm 0.2^{\mathrm{b}}$ & $7.6 \pm 0.3^{* * * a}$ \\
\hline
\end{tabular}

\footnotetext{
${ }^{1}$ Initial $\mathrm{pH}$ of the fermentation medium was $6.1 \pm 0.0$ for pea and $6.3 \pm 0.0$ for whey.

${ }^{2} L$. helveticus counts at the start of the fermentation were $6.3 \pm 0.1 \log _{10} \mathrm{cfu} / \mathrm{ml}$, for both proteins.

${ }^{3} \mathrm{~S}$. cerevisiae counts at the start of the fermentation were $5.7 \pm 0.1 \log _{10} \mathrm{cfu} / \mathrm{ml}$, for both proteins.

I = not applicable.

$*$ significant from the start value: $* P<0.05, * * P<0.01, * * * P<0.001$.

a, b = division in subsets by the factor "type of fermentation" by means of the Tukey post hoc test $(P<$ $0.05)$.
} 


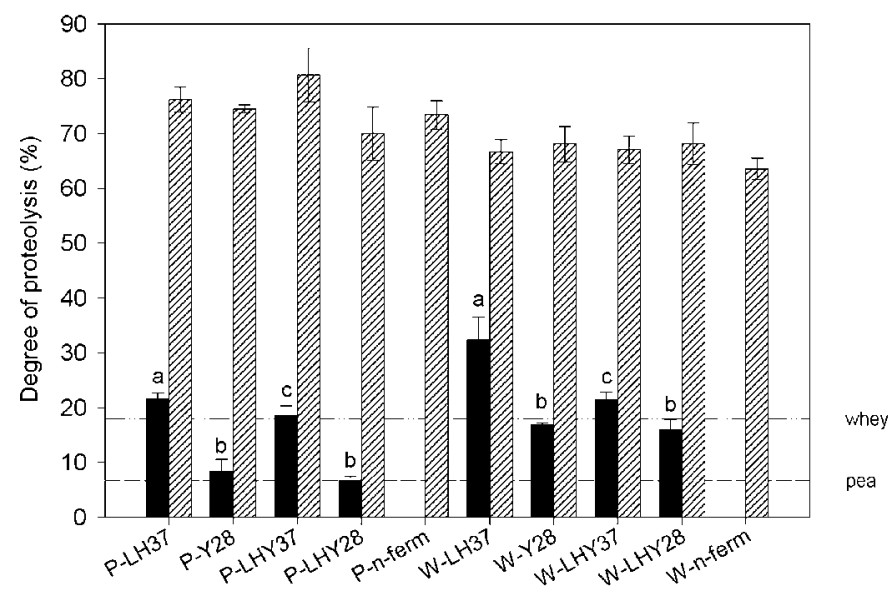

Figure 1. Degree of proteolysis (\%) after fermentation, and after fermentation and digestion of pea $(\mathrm{P})$ and whey $(\mathrm{W})$ protein. (LH37: Lactobacillus helveticus at $37^{\circ} \mathrm{C}$, Y28: Saccharomyces cerevisiae at $28^{\circ} \mathrm{C}$, LHY37: L. helveticus and $S$. cerevisiae at $37^{\circ} \mathrm{C}$, LHY28: $L$. helveticus and S. cerevisiae at $28^{\circ} \mathrm{C}, \mathrm{n}$-ferm: non-fermented). Black bars $=$ after fermentation, line pattern bars $=$ after fermentation and digestion; straight, dashed lines indicate the initial degree of proteolysis of the pea and whey medium.

$\mathrm{a}, \mathrm{b}, \mathrm{c}=$ division in subsets of the change in degree of proteolysis during fermentation and fermentation and digestion, by the factor "type of fermentation" by means of the Tukey post hoc test $(P<0.05)$.

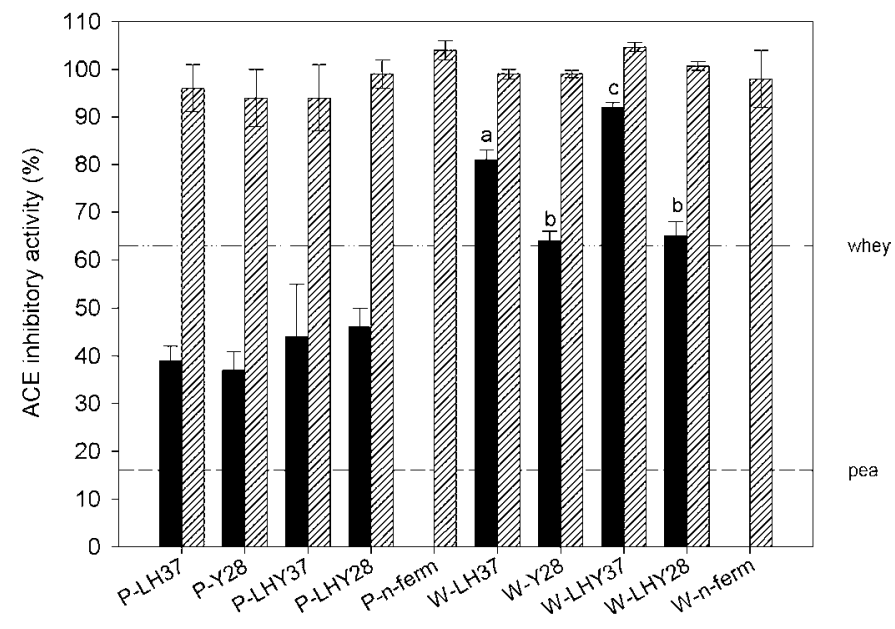

Figure 2. Angiotensin converting enzyme (ACE) inhibitory activity (\%) after fermentation, and after fermentation and digestion of pea (P) and whey (W) protein. (LH37: Lactobacillus helveticus at $37^{\circ} \mathrm{C}$, Y28: Saccharomyces cerevisiae at $28^{\circ} \mathrm{C}$, LHY37: L. helveticus and $S$. cerevisiae at $37^{\circ} \mathrm{C}$, LHY28: L. helveticus and $S$. cerevisiae at $28^{\circ} \mathrm{C}$, n-ferm: nonfermented). Black bars = after fermentation, line pattern bars = after fermentation and digestion; straight, dashed lines indicate the initial ACE inhibitory activity of the pea and whey medium.

$\mathrm{a}, \mathrm{b}, \mathrm{c}=$ division in subsets of the change in ACE inhibitory activity during fermentation, and fermentation and digestion, by the factor "type of fermentation" by means of the Tukey post hoc test $(P<0.05)$.
Table 3. 50\% inhibitory concentrations (IC50) (mg/ml) and 95\% confidence interval for the different types of fermentation for pea and whey protein. (LH37: Lactobacillus helveticus at $37^{\circ} \mathrm{C}$, Y28: Saccharomyces cerevisiae at $28^{\circ} \mathrm{C}$, LHY37: L. helveticus and $S$. cerevisiae at $37^{\circ} \mathrm{C}$, LHY28: L. helveticus and S. cerevisiae at $28^{\circ} \mathrm{C}, \mathrm{n}$-ferm: nonfermented).

\begin{tabular}{lrll}
\hline & & & $\begin{array}{l}\text { 95\% confidence } \\
\text { interval }\end{array}$ \\
\hline Pea & LH37 & 0.23 & $0.14-0.39$ \\
& Y28 & 0.18 & $0.13-0.25$ \\
& LHY37 & $0.16^{*}$ & $0.15-0.18$ \\
Why28 & 0.11 & $0.09-0.13$ \\
& n-ferm & 0.12 & $0.08-0.16$ \\
& LH37 & 0.14 & $0.12-0.16$ \\
& Y28 & 0.08 & $0.06-0.11$ \\
& LHY37 & 0.11 & $0.09-0.13$ \\
& LHY28 & $0.10^{*}$ & $0.08-0.12$ \\
& n-ferm & 0.07 & $0.04-0.10$ \\
\hline
\end{tabular}

* = Significantly different from each other $(P<0.05)$ as determined by the Games-Howell method.

The degree of proteolysis did not correlate with the ACE inhibitory activity: although the pea ferments at $28^{\circ} \mathrm{C}$ showed a lower degree of proteolysis compared with the pea ferments at $37^{\circ} \mathrm{C}$, the ACE inhibitory activity of both groups did not differ.

The $\mathrm{IC}_{50}$ value, the concentration of inhibitory compound necessary to inhibit the ACE enzyme for $50 \%$, enabled to further distinguish the ACE inhibitory activity of the digests (Table 3). Due to nonequal and, for some samples, large variances, the combined fermentation with $L$. helveticus and S. cerevisiae of the pea protein at $37^{\circ} \mathrm{C}$ and the combined fermentation with $L$. helveticus and S. cerevisiae of the whey protein at $28^{\circ} \mathrm{C}$ were the only samples that were significantly different. However, the whey digests tended to have a lower $\mathrm{IC}_{50}$, hence a higher ACE inhibitory activity, than the corresponding pea digests. The presence of the yeast at $28^{\circ} \mathrm{C}$ seemed to decrease the $\mathrm{IC}_{50}$ value. The lowest $\mathrm{IC}_{50}$ value was obtained in the nonfermented whey protein medium. For pea protein, the nonfermented sample had the one of the lowest $\mathrm{IC}_{50}$ value. Hence, the nonfermented samples were at least as ACE inhibitory active as the fermented ones.

\section{Protease Activity}

Protease activity in the 24-h propagated culture of $L$. helveticus and $S$. cerevisiae was measured on the supernatant and the cell precipitate in order to identify the origin of protease activity. The protease activity in the supernatant measured $0.80 \pm 0.01 \mathrm{U} / \mathrm{L}$ for $L$. helveticus and $0.53 \pm 0.07 \mathrm{U} / \mathrm{L}$ for $S$. cerevisiae. The cell precipitate of $L$. helveticus had a protease activity of $0.39 \pm 0.03 \mathrm{U} / \mathrm{L}$, whereas the one of $S$. cerevisiae had an activity of $0.55 \pm 0.13 \mathrm{U} / \mathrm{L}$. 


\section{HPLC Profiles}

The HPLC profile of the samples provided a fingerprint of the small peptides (MWCO ultrafiltration-centrifugation $=3000 \mathrm{Da}$ ) present in the digests. No real differences between the chromatograms of the fermented and the nonfermented digests were observed. For both proteins, the HPLC chromatogram of one fermented digest and the nonfermented digested medium are compared in Figure 3. The type of protein and the digestion step determined the HPLC profile and, hence, the formation of small peptides with possible ACE inhibitory effects.

\section{Contribution of Intracellular Proteases}

Nonautoclaved $40 \mathrm{~g} / \mathrm{L}$ pea and whey protein solution had a degree of proteolysis of $2.4 \pm 0.4$ and $12.9 \pm 0.7 \%$ $(P<0.001)$, respectively, and an ACE inhibitory activity of $10.0 \pm 0.7$ and $15 \pm 2 \%(P=0.083)$, respectively. After 24-h incubation with a suspension of lysed cells of $L$. helveticus at $37^{\circ} \mathrm{C}, S$. cerevisiae at $28^{\circ} \mathrm{C}$, and a combination of both at $37^{\circ} \mathrm{C}$, the degree of proteolysis increased only for the pea protein and amounted to $30 \%$ at the end of digestion for all suspensions. Similarly, for the pea protein only, an increase in ACE inhibitory activity was observed. The ACE inhibitory activity reached after incubation $80 \%$ for S. cerevisiae, $30 \%$ for L. helveticus, and $40 \%$ for the combination lysed cells. In the whey protein digests, no change in degree of proteolysis, nor ACE inhibitory activity, could be detected.

\section{DISCUSSION}

In this study, pea and whey protein were fermented by lactobacilli and yeast in order to release ACE inhibitory peptides that could lower the blood pressure in vivo. Subsequently, the impact of an in vitro gastrointestinal digestion on the ACE inhibitory activity was evaluated.

From the eight GRAS lactobacilli selected, only $L$. helveticus produced considerable ACE inhibitory activity after fermentation of pea protein medium. L. helveticus, whether or not in combination with $S$. cerevisiae, is known for its capacity to form ACE inhibitory peptides from milk proteins (Nakamura et al., 1995; Yamamoto et al., 1999). Fermented milk prepared by most strains of $L$. helveticus significantly lowers the blood pressure in SHR upon oral administration, while milk fermented by other species of lactic acid bacteria, among which was a L. acidophilus strain, does not display significant antihypertensive effects (Yamamoto et al., 1994b). According to the same study, ACE inhibitory activity in most of the whey fractions of the milk fermented with $L$. helveticus is also higher than in the other fermented
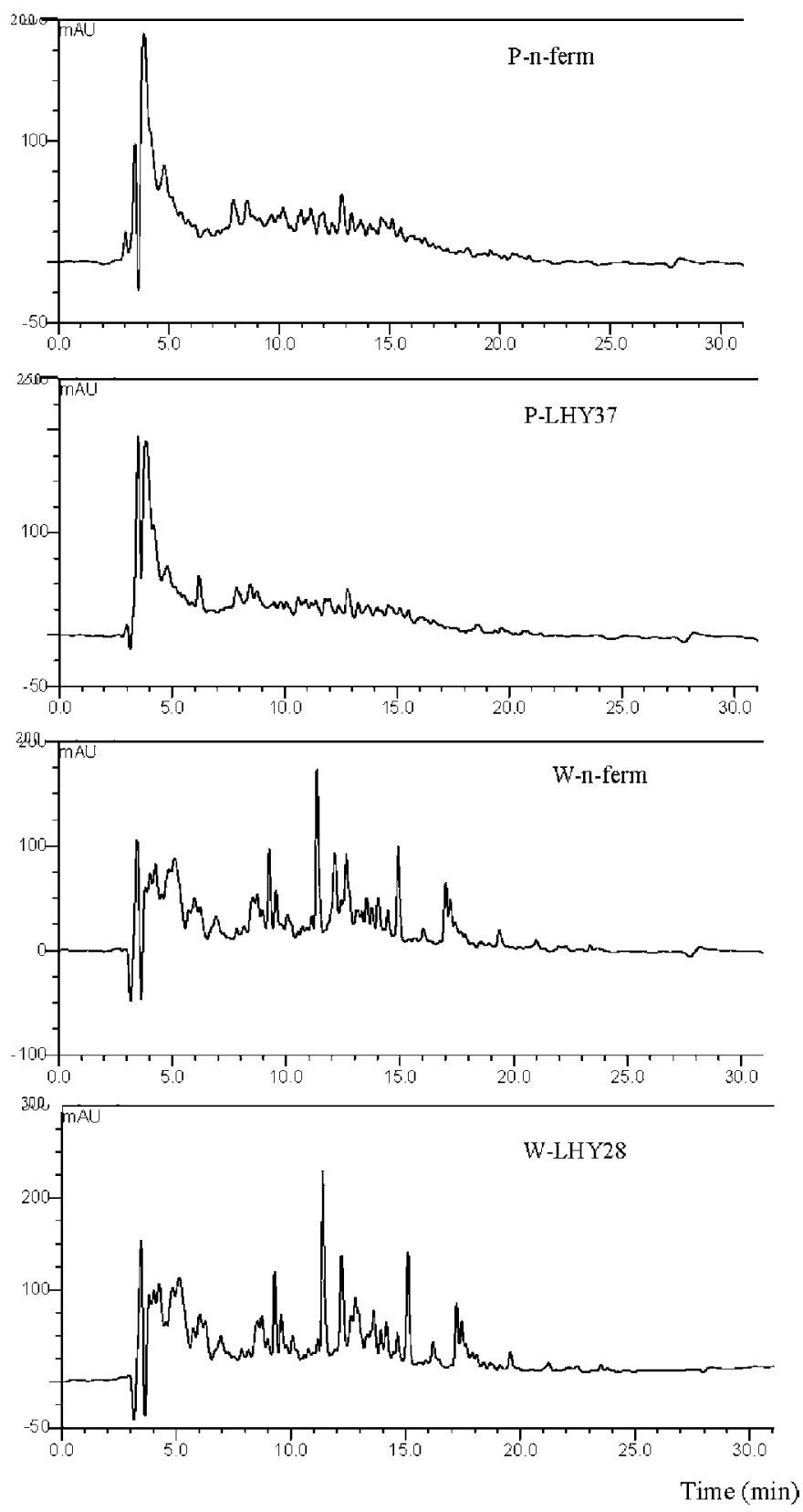

Figure 3. HPLC-profile of the digested nonfermented pea (P-nferm) and whey (W-n-ferm) medium, pea medium fermented with $L$. helveticus at $37^{\circ} \mathrm{C}$ (P-LHY37) and whey medium fermented with $S$. cerevisiae at $28^{\circ} \mathrm{C}$ (W-LHY28).

milks. Nevertheless, ACE inhibitory peptides have been isolated from different dairy products started by lactic acid bacteria: e.g., Lactobacillus delbrueckii subsp. bulgaricus SS1, Lactococcus lactis subsp. cremoris FT4, Lactobacillus acidophilus, bifidobacteria, and Streptococcus thermophilus (Gobbetti et al., 2000; Saito et al., 2000; Ryhänen et al., 2001). 
Based on the results from the screening and literature, L. helveticus and S. cerevisiae were subsequently used to initiate fermentations in monoculture and in combination on pea and whey protein. The ACE inhibitory activity after fermentation is not a good selection criterion, because the physiological transformations in the human body, which determine the bioavailability of the ACE inhibitory peptides, are not taken into consideration. However, often only the food-processing step is envisaged (Haileselassie et al., 1999; Kim et al., 2001). By incorporation of the in vitro gastrointestinal digestion, the measured ACE inhibitory activity relates more closely to the ACE inhibitory activity in the human body. To exert an antihypertensive effect, the peptides also have to pass the intestinal barrier to arrive in the blood in an active form, an issue which has been the scope of another paper (Vermeirssen et al., 2002a). From this study, it was hard to make a selection after in vitro digestion, since almost all fermented digests reached maximum ACE inhibitory activity.

The lactic acid bacterium $L$. helveticus was metabolically more active at $37^{\circ} \mathrm{C}$, and this resulted in more lactic acid production and, hence, a larger $\mathrm{pH}$ decrease. Although $L$. helveticus and S. cerevisiae have complex nutritional requirements for growth (Walker, 1998; Hebert et al., 2000), both microorganisms were able to grow on the pea and whey protein medium in monoculture at their optimal temperature. The type of protein did not influence their growth, showing that pea and whey protein both could serve as a nitrogen source for $L$. helveticus and S. cerevisiae. In the combined fermentations, the yeast did not favor the growth of $L$. helveticus, which could be due to the production of, e.g., organic acids, antibacterial compounds, ethanol,or competition for nutrients. The counts of $S$. cerevisiae, on the other hand, decreased slightly in the presence of $L$. helveticus at $37^{\circ} \mathrm{C}$, which can either be attributed to the high acid production or the high temperature.

The increase in degree of proteolysis observed in the ferments with $L$. helveticus was induced by the action of its proteases, possibly supplemented by a slight acid hydrolysis. L. helveticus is known to possess a cell-wallassociated protease, capable of forming antihypertensive peptides from casein (Yamamoto et al., 1994a), and several peptidases (Christensen et al., 1999). However, the protease activity assay found a higher activity in the supernatant than in the cell precipitate, indicating that the cell-wall-associated protease has been released from the cell wall or that other secreted proteases played a major role. Also, the peptide-rich propagation medium may inhibit the synthesis of the cell-wall-associated protease in L. helveticus (Hebert et al., 2000). The total potential protease activity of $S$. cerevisiae was similar to the one of $L$. helveticus, but this was not translated into an increase in degree of proteolysis after fermentation. Generally, S. cerevisiae has no extracellular proteases or peptidases to cleave oligopeptides or proteins in the medium, only some specialized strains have (Walker, 1998). However, it seems that the strain used in this study did possess some extracellular protease activity. A nonsignificant increase and even decrease in degree of proteolysis by the yeast can be explained by the consumption of peptides and amino acids present in the medium and by an increase in total protein content due to yeast growth. The gastrointestinal proteases sharply increased the degree of proteolysis, which simulated well the conditions during physiological digestion. The specificity and purity of pepsin, tryp$\sin$, and $\alpha$-chymotrypsin led to the formation of numerous peptides and amino acids. The pea protein was more susceptible to hydrolysis than the whey protein.

Autoclaving had a major impact on the ACE inhibitory activity of the heat labile whey protein. This may be caused by the presence of natural proteases in the whey protein isolate, which are initially activated by the temperature increase during autoclaving. In vitro gastrointestinal digestion released significant ACE inhibitory activity from pea and whey protein medium and ferments. However, despite the growth of the microorganisms, the increase in degree of proteolysis and the increase in ACE inhibitory activity after fermentation, the fermented samples did not show higher ACE inhibitory activity after in vitro digestion than the nonfermented samples. Fermentations ineffective in producing ACE inhibitory activity have been reported in literature. Pihlanto-Leppällä et al. (1998) observed ACE inhibitory activity in whey and casein fermented with different lactic acid starters only after digestion by trypsin and pepsin. They attribute their results to the low proteolytic activity of the starters or the specificity of the enzymes in lactic acid bacteria. The formation of bioactive peptides by lactic acid bacteria seems to be a rare event and is recently being debated (Meisel and Bockelmann, 1999). The $\mathrm{IC}_{50}$ values not only confirmed this observation, but even pointed out that fermentation may sometimes adversely affect the ACE inhibitory activity as the nonfermented whey protein digest showed the highest ACE inhibitory activity. The tendency towards higher $\mathrm{IC}_{50}$ values in the fermented digests can be enlightened by the hypothesis that the microbial enzymes split within the sequence of bioactive peptides in the food protein, thereby preventing the gastrointestinal proteases to release them. Therefore, there exists an optimal degree of hydrolysis, above which more ACE inhibitory peptides are degraded than new peptides are formed, decreasing the overall ACE inhibitory activity (Mullally et al., 1997). Hence, no direct relationship between the degree of proteolysis 
and the ACE inhibitory activity is possible, especially in the later stages of hydrolysis. However, after fermentation of the whey but not the pea protein, some correlation between the degree of proteolysis and the ACE inhibitory activity was observed. The $\mathrm{IC}_{50}$ values of the digests ranged from 0.07 to $0.23 \mathrm{mg} / \mathrm{ml}$, which are slightly more active than the values reported for whey digests by gastrointestinal proteases of 0.35 to $1.73 \mathrm{mg} /$ $\mathrm{ml}$ (Pihlanto-Leppällä et al., 2000). Differences in assay conditions make it somehow difficult to compare these values. The tendency towards lower $\mathrm{IC}_{50}$ values for the whey compared to the pea digests was due to the intrinsic amino acid sequence of the protein.

Furthermore, the HPLC chromatograms of the peptide fraction with MWCO $<3000 \mathrm{Da}$, did not differ between fermented and nonfermented digests. In vitro digestion resulted in the formation of small peptides, which possibly possess ACE inhibitory and antihypertensive effects. Matar et al. (1996), however, concluded that there is a major impact of milk fermentation by $L$. helveticus on subsequent gastrointestinal digestion. The HPLC elution profiles of that study show that fermentation may contribute to the formation of new peptides during in vitro digestion, provided that the $\mathrm{pH}$ is controlled at 6.0 during the fermentation, which favors the proteolytic activity of $L$. helveticus. Nevertheless, in other fermentation studies with $L$. helveticus and other lactic acid bacteria that were effective in producing ACE inhibitory peptides, $\mathrm{pH}$ was never controlled (Nakamura et al., 1995; Yamamoto et al., 1999; Gobbetti et al., 2000).

In the case of the pea protein, the preliminary study on the production of ACE inhibitory activity from lysed cells pointed to the importance of the intracellular proteases from $S$. cerevisiae. Lysis of the cells made these proteases readily available for splicing off the bioactive peptide sequences from the food proteins. Intracellular proteases and peptidases of both $L$. helveticus and $S$. cerevisiae will most likely contribute to degradation of proteins after cell lysis (Meisel and Bockelmann, 1999). High ACE inhibitory activity is identified in skimmed milk digested with cell-free extract of $S$. cerevisiae, and the hydrolysate obtained with the purified protease $\mathrm{B}$ shows an $\mathrm{IC}_{50}$ of $0.42 \mathrm{mg}$ protein/ml (Roy et al., 2000). An extract of autologous Lactobacillus casei cell lysate shows an antihypertensive effect in hypertensive patients, but this is due to the presence of polysaccharideglycopeptide complexes (Nakajima et al., 1995).

\section{CONCLUSIONS}

We were able to produce ACE inhibitory active digests from pea and whey protein. Nevertheless, a fermentation step by $L$. helveticus or/and $S$. cerevisiae did not improve the release of ACE inhibitory activity after in vitro gastrointestinal digestion. The formation and degradation of ACE inhibitory activity during gastrointestinal digestion and absorption merit further work.

\section{ACKNOWLEDGMENTS}

This work was supported by a Ph.D. grant (aspirant) for Vanessa Vermeirssen from the Fund for Scientific Research-Flanders [Fonds voor Wetenschappelijk Onderzoek (FWO) Vlaanderen]. Kris Van Hege, Tom Van de Wiele, and Kristof Verthé are gratefully acknowledged for revising the manuscript. We thank Steven Siciliano for the helpful discussions and statistical assistance.

\section{REFERENCES}

Abubakar, A., T. Saito, H. Kitazawa, Y. Kawai, and T. Itoh. 1998. Structural analysis of new antihypertensive peptides derived from cheese whey protein by proteinase K digestion. J. Dairy Sci. 81:3131-3138.

Campbell, D. J. 1987. Circulating and tissue angiotensin systems. J. Clin. Invest. 79:1-6.

Christensen, J. E., E. g. Dudley, J. A. Pederson, and J. L. Steele. 1999. Peptidases and amino acid catabolism in lactic acid bacteria. Antonie Van Leeuwenhoek 76:217-246.

De Boever, P., B. Deplancke, and W. Verstraete. 2000. Fermentation by gut microbiota cultured in a simulator of the human intestinal microbial ecosystem is improved by supplementing a soygerm powder. J. Nutr. 130:2599-2606.

Duprez, D., P. Van Helshoecht, W. Van den Eynde, and M. Leeman. 2002. Prevalance of hypertension in the adult population of Belgium: report of a worksite study, Attention Hypertension. J. Hum. Hypertens. 16:47-52.

Dziuba, J., P. Minkiewicz, and D. Nalecz. 1999. Biologically active peptides from plant and animal proteins. Pol. J. Food. Nutr. Sci. 8:3-16.

Fitzgerald, R. J., and H. Meisel. 2000. Milk protein-derived peptide inhibitors of angiotensin-I-converting enzyme. Br. J. Nutr. 84:S33-S37.

Ganong, W. F. 1997. Section V. Gastrointestinal function. Pages 437481 in Review of Medical Physiology. Appleton \& Lange, Stamford, CT, US.

Gauthier, S. F., C. Vachon, and L. Savoie. 1986. Enzymatic conditions of an in vitro method to study protein digestion. J. Food Sci. 51:960-964.

Gobbetti, M., P. Ferranti, E. Smacchi, F. Goffredi, and F. Addeo. 2000. Production of angiotensin-I-converting-enzyme-inhibitory peptides in fermented milks started by Lactobacillus delbrueckii subsp. bulgaricus $\mathrm{SS} 1$ and Lactococcus lactis subsp. cremoris FT4. Appl. Environ. Microbiol. 66:3898-3904.

Haileselassie, S. S., B. H. Lee, and B. F. Gibbs. 1999. Purification and identification of potentially bioactive peptides from enzymemodified cheese. J. Dairy sci. 82:1612-1617.

Hata, Y., M. Yamamoto, M. Ohni, K. Nakajima, Y. Nakamura, and T. Takano. 1996. A placebo controlled study of the effect of sour milk on blood pressure in hypertensive subjects. Am. J. Clin. Nutr. 64:767-771.

Hebert, E. M., r. r. raya, and G. S. De Giori. 2000. Nutritional requirements and nitrogen-dependent regulation of proteinase activity of Lactobacillus helveticus CRL 1062. Appl. Environ. Microbiol. 66:5316-5321.

Hermansen, K. 2000. Diet, blood pressure, and hypertension. Br. J. Nutr. 83:113-119. 
Kim, S. K., H. G. Byun, P. J. Park, and F. Shahidi. 2001. Angiotensin I converting enzyme inhibitory peptides purified from bovine skin gelatin hydrolysate. J. Agric. Food Chem. 49:2992-2997.

Matar, C., J. Amiot, L. Savoie, J. Goulet. 1996. The effect of milk fermentation by Lactobacilus helveticus on the release of peptides during in vitro digestion. J. Dairy Sci. 79:971-979.

Meisel, H., and W. Bockelmann. 1999. Bioactive peptides encrypted in milk proteins: proteolytic activation and thropho-functional properties. Antonie Van Leeuwenhoek 76:207-215.

Mullally, M., H. Meisel, and R. J. Fitzgerald. 1997. Angiotensin-1converting enzyme inhibitory activities of gastric and pancreatic proteinase digests of whey proteins. Int. Dairy J. 7:299-303.

Nakajima, K., Y. Hata, Y. Osono, M. Hamura, S. Kobayashi, and M. Watanuki. 1995. Antihypertensive effect of extracts of Lactobacillus casei in patients with hypertension. J. Clin. Biochem. Nutr. 18:181-187.

Nakamura, Y., N. Yamamoto, K. Sakai, A. Okubo, S. Yamazaki, and T. Takano. 1995. Purification and characterization of angiotensin I-converting enzyme inhibitors from a sour milk. J. Dairy Sci. 78:777-783.

Pihlanto-Leppällä, A., T. Rokka, and H. Korhonen. 1998. Angiotensin I-converting enzyme inhibitory peptides from bovine milk proteins. Int. Dairy J. 8:325-331.

Pihlanto-Leppällä, A., P. Koskinen, K. Piilola, T. Tupasela, and H. Korhonen. 2000. Angiotensin I-converting enzyme inhibitory properties of whey protein digests: concentration and characterization of active peptides. J. Dairy Res. 67:53-64.

Pihlanto-Leppällä, A. 2001. Bioactive peptides derived from bovine whey proteins: opioid and ACE inhibitory peptides. Trends Food Sci. Tech. 11:347-356.

Roy, M. K., Y. Watanabe, and Y. Tamai. 2000. Yeast protease Bdigested skimmed milk inhibits angiotensin-I-converting-enzyme activity. Biotechnol. Appl. Biochem. 31:95-100.

Ryhänen, E.-L., A. Pihlanto-Leppällä, and E. Pahkala. 2001. A new type of ripened, low-fat cheese with bioactive properties. Int. Dairy J. 11:441-447.
Saito, T., T. Nakamura, H. Kitazawa, Y. Kawai, and T. Itoh. 2000. Isolation and structural analysis of antihypertensive peptides that exist naturally in Gouda cheese. J. Dairy Sci. 83:1434-1440.

Sipola, M., P. Finckenberg, J. Santisteban, R. Korpela, H. Vapaatalo, and M. L. Nurminen. 2001. Long-term intake of milk peptides attenuates development of hypertension in spontaneously hypertensive rats. J. Physiol. Pharmacol. 52:745-754.

Sokal, R. R., and F. J. Rohlf. 1995. Chapter 13. Assumptions of analysis of variance. Pages 392-450 in Biometry. The principles and Practice of Statistics in Biological Research. W. H. Freeman and Company, New York, NY, US.

Takano, T. 1998. Milk derived peptides and hypertension reduction. Int. Dairy J. 8:375-381.

Vermeirssen, V., B. Deplancke, K. A. Tappenden, J. Van Camp, H. R. Gaskins, and W. Verstraete. 2002a. Intestinal transport of the lactokinin Ala-Leu-Pro-Met-His-Ile-Arg through a Caco-2 Bbe monolayer. J. Pept. Sci. 8:95-100.

Vermeirssen, V., J. Van Camp, and W. Verstraete. 2002b. Optimization and validation of an Angiotensin Converting Enzyme (ACE) inhibition assay for the screening of bioactive peptides. J. Biochem. Biophys. Meth. 51:75-87.

Viljoen, B. C. 2001. The interaction between yeasts and bacteria in dairy environments. Int. J. Food Microbiol. 69:37-44.

Walker, G. M. 1998. Yeast Physiology and Biotechnology. John Wiley \& Sons, Ltd., Chichester, U.K.

Yamamoto, N., A. Akino, and T. Takano. 1994a. Antihypertensive effect of the peptides derived from casein by an extracellular proteinase from Lactobacillus helveticus CP790. J. Dairy Sci. 77:917-922.

Yamamoto, N., A. Akino, and T. Takano. 1994b. Antiohypertensive effects of different kinds of fermented milk in spontaneously hypertensive rats. Biosci. Biotechnol. Biochem. 58:776-778.

Yamamoto, N., M. Maeno, and T. Takano. 1999. Purification and characterization of an antihypertensive peptide from a yogurtlik product fermented by Lactobacillus helveticus CPN4. J. Dairy Sci. 82:1388-1393. 